DOI: 10.14526/2070-4798-2019-14-2-83-88

\title{
Psychosemantic study of highly-qualified athletes' motivation
}

\author{
Vadim G. Afanasev ${ }^{1 *}$, Igor L. Solomin ${ }^{2}$, Lada Yu. Solomina ${ }^{3}$ \\ ${ }^{1}$ HB-Assistance, Saint Petersburg, Russia \\ ORCID: 0ooo-0001-6522-9138, info@hbagr.ru \\ ${ }^{2}$ Emperor Alexander I St. Petersburg State Transport University \\ Saint Petersburg, Russia \\ ORCID: 0000-0002-3354-0666, info@hbagr.ru \\ ${ }^{3}$ The Center of Psychological-Pedagogical, Medical and Social Assistance of St. Petersburg \\ Petrodvorets District "Doverie", \\ Saint Petersburg, Russia \\ ORCID: 0000-0002-9935-5009, info@hbagr.ru
}

\begin{abstract}
The article presents the results of professional athletes' motivation psychosemantic study. We revealed the content of professional athletes' needs, motives and attitudes. The athletes presented hockey, cycling, rowing and canoeing, sambo-wrestling, biathlon and yachting sport. Materials. The data, received as a result of an individual and group form of motivation diagnostics, with the help of forms and specially created Express computer program. Research methods. The methodology of psychosemantic express-diagnostics is created by Igor L. Solomin on the basis of color metaphors method. Results. The results analysis of motivation psychosemantic study among professional athletes, who go in for hockey, cycling, rowing and canoeing, sambo-wrestling, biathlon and yachting sport, helped to define motivational problems, reveal motivational resources and compare the content of motivation among male and female professional athletes. The main motiva-tional problems of athletes include insufficient satisfaction with life, lack of close communication relations in team, indifference concerning Russia and the absence of desire to learn. Motivation resources include the following: keenness on sports activity. It is connected with sport plans, self-respect, trust-based relations with the coach, the value of work and family in life. As a result of motivation content comparison between men and women it was revealed that female athletes need additional work, directed toward their psychological, social and professional adaptation. Conclusion. The methodology of psychosemantic diagnostics, in particular color metaphors method, can be recommended for motivation parameters revelation and its dynamics control among professional ath-letes.

Keywords: athletes, personality, motivation, needs, motives, relations, consciousness, notions, psychosemantics, psychodiagnostics.
\end{abstract}

For citation: Vadim G. Afanasev, Igor L. Solomin, Lada Yu. Solomina. Psychosemantic study of highlyqualified athletes' motivation. The Russian Journal of Physical Education and Sport. 2019; 14(2): 71-74. DOI 10.14526/2070-4798-2019-14-2-83-88.

\section{URGENCY}

Motivation is one of the most significant factors. It defines the content and success of a person's activity. Motivation diagnostics with the help of direct questioning methods and questionnaire survey reveals declared needs, motives and relations. They can be demonstrated or concealed by the respondents. Not declared motivation diagnostics is possible with the help of the experimental psychosemantics methods. They reveal the content of an individual and group consciousness, a person's notions and attitudes, unconscious experience [1-5].

It is interesting to realize psychosemantic study of highly-qualifies athletes' motivational sphere content.

The aim of the research is to reveal the content of needs, motives and attitudes of highly-qualified athletes. They present different kinds of sport.

\section{RESEARCH METHODS}

The research was held during June-August 2018 at the training centers of Moscow, Moscow and Leningrad regions. 109 highly-qualified athletes were examined, including 80 men and 29 women. There were 16 sambo wrestlers, 28 hockey players, 15 biathletes and 8 yachting sport representatives among the respondents. Among the examined hockey players and rowers there were only men and among sambo wrestlers, cyclists, biathletes and 
yachting sport representatives there were both men and women.

In order to reveal not declared motivation of athletes we used psychosemantic expressdiagnostics. It is created by Igor L. Solomin [2$5]$ on the basis of color metaphors method. The methodology is created to reveal the content of needs, motives and attitudes.

We offered a respondent 100 notions. They characterize different needs and values, lessons and kinds of activity, people and groups of people, events and feelings. A respondent has to define each of these notions with the help of one of 8 presented colors: blue, green, red, yellow, violet, brown, black or gray. After that the respondent ranges colors according to attractiveness: from the most pleasant to the most disgusting. Data acceptance can be realized in an individual and group form with the help of forms or specially created Express computer program and demands 10-15 minutes. For group data handling Express program is used.

During the notion marking (the most pleasant and the most unpleasant color) we make the conclusion about the most positive and negative emotional attitude to this notion. If several notions are marked with the same color we make the conclusion that these notions are accepted as similar, close in a respondent's consciousness. According to each group of respondents we make a matrix of each notion similarity with another notion in group consciousness with the help of Express computer program. If more than $33 \%$ of respondents mark two notions with one color these notions are considered associated in group consciousness.

We analyze which notions are associated with the following notions: "My hobby", "An interesting activity", "My present", "My future", "What kind of person I am in reality", "What kind of person I want to be", "My profession", "Going in for sports", "Trainings", "Competitions", "My coach", "My team" and others. Thus, we reveal the content of the basic and urgent needs, interests and hobbies, needs satisfaction, attitude to the future, "Real self" image correspondence with "Ideal self" image, being pleased with oneself and the level of self-assessment, attitude to the coach and team, attitude to sport and the motives of sports activity, needs. They motivate to realize other kinds of activity: own profession, work, studying, business and etc.

\section{RESULTS AND DISCUSSION}

We received the following results of psychosemantic motivation study. They characterize the whole sampling of athletes:

- sport, profession and work, together with family relations are closely connected with the interests of athletes and are understood as hobbies and present independent value. They are not considered as the means of other needs satisfaction;

- athletes in most cases are characterized by difficulties in the leading needs satisfaction; life in present moment and in the expected future, as a rule, is not considered by them as something interesting and fascinating;

- now athletes are focused on the notions of their personality and profession. Sport is not the reason for real trials;

- athletes expect changes in the future. Their plans are connected with sport, profession and work more that the present;

- most athletes are characterized by maximum high level of self-esteem. They are satisfied with own personality;

- sports activity is motivated by basic needs in self-actualization and self-affirmation. The role of material needs in sport motivation is insignificant;

- athletes are inclined to identify themselves with a coach. The coach is accepted as a person, who is like them. That is why the coach is a close person, who can be trusted;

- as a rule, athletes don't have close emotional relations with the team;

- most athletes are not characterized by patriotism;

- work and family are equally interesting and important for the athletes;

- athletes have no motives to realize educational activity;

- in most cases there is no desire to have business.

Thus, we can define the following motivational problems: insignificant satisfaction with life in the present, lack of close relations in team, indifference to Russia and almost no desire to study. The motivational resource, which can be used in work 
with the athletes, is keenness on sports activity. It is connected with sport plans, self-respect, trust in the coach, value of work and family in life.

It is interesting to compare the content of motivation among men and women. They are highly-qualified athletes. The results prove that in comparison with male athletes female athletes have more restricted range of interests, less hope for the basic needs satisfaction in the future, less anxiety level concerning the problems of relations in the present, less keenness on sport, less close relations with the coach and the team, less patriotic attitude to Russia, less expressed desire to work. In other words, female respondents have more distinct psychological problems. They are seen in general and sports motivation deficiency, in unsatisfied needs, in distance with the coach and the team. Thus, female athletes need additional work. It is directed toward their psychological, social and professional adaptation. Moreover, it is reasonable to check this fact and reveal the reason for disadaptation among women in the sphere of professional sport.

We revealed considerable differences in motivation content and the attitude of different kinds of sport representatives. In comparison with steady individual-typological peculiarities of a personality consciousness content is more susceptible to the specificity of activity, environmental conditions, social relations and other conditions. Situational conditionality of the needs, notions and relations helps to use psychosemantic methods for the objectives of athletes' motivational sphere monitoring during sports training and activity. In particular, it was revealed that in comparison with other kinds of sport the examined group of cyclists is characterized by some problems in motivational sphere. They are the following: general level of impulses decrease, less optimistic attitude to the future, lower self-assessment, less satisfaction with own personality, less keenness on sport, competitions and trainings, less positive attitude to the coach and team, greater indifference to work. Only a positive attitude to family helps them to preserve interest in life. It should be noted that these results are proved by the results of a personal typological survey. They prove high specific weight of personality accentuation dysthymic type among the examined representatives of cycling. Thus, cyclists need additional examination for the reasons of emotional problems revelation and taking measures. They are directed toward psychological help realization.

\section{CONCLUSION}

The received results help to define the characteristics of motivation and athletes' attitudes. They provide effectiveness increase of their training and sports activity:

- a wide range of interests and hobbies, need for the material well-being, recognition, health; communicative, cognitive, aesthetic and moral needs and values;

- the opportunity to satisfy these needs in present and hope to satisfy them in the future, optimistic attitude to the future;

- maximum high level of self-assessment, being pleased with own personality, self-esteem;

- the attitude to sport as to a hobby and an interesting activity, attention focusing on sport in present and connected with sport plans for the future;

- identification, understanding and having trust in a coach, considering the coach as the example;

- identification with the team, treating the team friendly like a family;

- identification with the family;

- identification with Russia, the attitude to Russia like to a father;

- considering work an interesting and fascinating activity, focus on work in the present and work connection with the future plans;

- interest in educational activity;

- the absence of excessive interest in business.

In order to reveal these motivation parameters and its dynamics control we can recommend the method of psychosemantic diagnostics, in particular, the methodology of color metaphors.

\section{REFERENCES}

1. Solomin I.L. Sovremennye metody psihologicheskoj ekspress-diagnostiki I professional'nogo konsul'tirovaniya [Modern methods of psychological express-diagnostics and professional counseling]. Saint Petersburg: Rech. 
2006: 210.

2. Solomin I.L. Using the method of color metaphors for schoolchildren's structure of emotional attitudes diagnostics. Pedagogicheskaya diagnostika. 2015; 2:75-86 (In Russ.).

3. Solomin I.L. Praktikum popsihodiagnostike. Psihosemanticheskie metody: Uchebnometodicheskoe posobie [Psychodiagnostics workshop. Psychosemantic methods: Educational manual]. Saint Petersburg: PGUPS. 2013: 96.

4. Reinboth M., Duda J.L. Motivational climate, perceived ability and athletes' psychological and physical well-being: A longitudinal perspectives. Psychology of Sport and Exercise. 2004; 7: 269-286.

5. Reinboth M., Duda J.L. Perceived motivational climate, need satisfaction and indices of well-being in team sports: A longitudinal perspectives. Psychology of Sport and Exercise. 2006; 7: 269-286.

6. Ryan R.M., Deci E.L. Intrinsic and extrinsic motivations: Classic definitions and new directions. Contemporary Educational Psychology. 2000; 25: 54-67.

7. Standage M., Duda J.L., Ntoumanis N. Predicting motivational regulations in physical education: the interplay between dispositional goal orientations, motivational climate and perceived competence. Journal of Sports Sciences. 2003; 21: 631-647.

8. Standage M., Duda J.L., Pensgaard A. The Effect of Competitive Outcome and Task-Involving, Ego-Involving, and Cooperative Structures on the Psychological Well-Being of Individuals Engaged in a Co-Ordination Task: A Self-Determination Approach. Motivation and Emotion. 2005; 29(1): 41-68.

9. Vallerand R.J., Rousseau F. Intrinsic and extrinsic motivation in sport and exercise: a review using the hieratchical model of intrinsic and extrinsic motivation. Handbook of Sport Psychology. 2001: 389-416.

10. Osipov D.A. Motivational Sphere and Memory Improvement as Structural Components a Boxers Motor Skills Afferent Synthesis. Pedagogikopsihologicheskie I medico-biologicheskie problemy fizicheskoj kul'tury I sporta = The Russian-Journal of Physical Education and Sport. 2018; 13(3): 44-50. DOI: $10.14526 / 2070-4798-2018-13-3-57-65$.

Submitted: 30.03.2019

\section{Author's information:}

Vadim G. Afanasev - Master of Physical Education, Psychodiagnostics Consultant, HBAssistance, 1950o9, St. Petersburg., Mikhailov str., House 12, Office13H, e-mail: info@hbagr.ru

Igor L. Solomin - Candidate of Psychology, Associate Professor, Emperor Alexander I St. Petersburg State Transport University, 195009, Saint-Petersburg, Mikhailov str., House 12, Office13H, e-mail: info@hbagr.ru

Lada Y. Solomina - Candidate of Psychology, Associate Professor, The Center of PsychologicalPedagogical, Medical and Social Assistance of St. Petersburg Petrodvorets District "Doverie", SaintPetersburg, 1950o9, Saint-Petersburg, Mikhailov str., House 12, Office13H, e-mail: info@hbagr.ru 